技術報告

\title{
伊賀市におけ $\mathrm{BDF}$ 製造による $\mathrm{CO}_{2}$ 発生量削隇試算 - $\mathrm{CO}_{2}$ 発生係数による簡易試算の試み一
}

\author{
加藤進 ${ }^{*}$, 紀平征 希*, 小林康志** \\ 八木田浩史***, 前田広人*
}

\section{要旨}

$\mathrm{BDF}$ に伴う $\mathrm{CO}_{2}$ 削減量試算を $\mathrm{CO}_{2}$ 発生係数によって推定した. $\mathrm{BDF}$ の品質は, 水分と FAME 純度を除 きニート基準を満足していた，年間 $\mathrm{BDF}$ の製造量は8256Lで，これを基礎に削減 $\mathrm{CO}_{2}$ 量を試算した。単純 計算では21796 kg-CO2/y が削減，軽油との発熱量換算を実施すると，20381 $\mathrm{kg}-\mathrm{CO}_{2} / \mathrm{y}$ となった. BDFの製 造試薬 $\left(\mathrm{KOH}\right.$ とメタノール)を加味すると， $17850 \mathrm{~kg}-\mathrm{CO}_{2} / \mathrm{y}$ となった，電力量を考慮すると $17436 \mathrm{~kg}-\mathrm{CO}_{2} / \mathrm{y}$ まで減少した。な拈，境界システムを考慮すると， $17305 \mathrm{~kg}-\mathrm{CO}_{2} / \mathrm{y}$ となった。

キーワード： $\mathrm{BDF}, \mathrm{CO}_{2}$ 削減試算, 原料, 電力量

\section{1.はじめに}

三重県中央部の伊賀市では，人口が減少，過疎化， 疲弊した農林部分の活性化をするためにバイオマス夕 ウン構想を打ち立てた。 なかでもこの構想の重要な骨 子が「菜の花プロジェクト」である。この伊賀「菜の 花プロジェクト」では廃食油あるいは菜種からバイオ ディーゼル燃料（BDF）の製造を実施する部分が計 画の大きな骨子の一つである。すでに，平成 21 年 6 月 に $\mathrm{BDF}$ 製造所を開所以来 1 年間以上が経過した。

このプロジェクトの主眼は, (1)農村部分の活性化 あるいは都市部との交流および(2)地球温暖化防止 ( = $\mathrm{CO}_{2}$ 量の削減)である.このような活動部署(伊賀市 では農林振興課)では, プロジェクトの実施によって 実際に削減した $\mathrm{CO}_{2}$ 量の公表を求められることが多 い. しかしながら, 現在の $\mathrm{CO}_{2}$ 削減量計算の主流はラ イフサイクルアセスメント（LCA）であり，対象と なる小規模事業所では容易に計算できるものではな
い.そのために, 先行する「菜の花プロジェクト」や 「BDF 製造に伴うエコ活動」をしている団体では, $\mathrm{BDF}$ 製造に伴う「 $\mathrm{CO}_{2}$ 発生削減量」として BDF 製造 量に軽油の $\mathrm{CO}_{2}$ 発生係数 $\left(2.64 \mathrm{~kg}-\mathrm{CO}_{2} / \mathrm{L}\right)$ を乗じて 報告している場合が多い. 削減量把握は行政的にも重 要な因子であり, web-site 等に同様の試算結果が報 じられている。この削減量には当然のことであるが, $\mathrm{BDF}$ を製造する際に利用する副原料(メ夕ノール等), 電力量および廃グリセリン等の考慮がなされていない ので，計算された $\mathrm{CO}_{2}$ の削減量は過大評価されている ことになる。

したがって，高価なソフトウエアーによる LCA 評 価 $^{1)}$ よりも簡易的に, 上記の寄与も含めて $\mathrm{CO}_{2}$ の削 減量を試算する手法があれば当該従事者には便利と思 われる。本報では，製造したBDFの品質を化学分析 によって明らかにすると同時に，1 年間の試験的運用 の結果，重大なトラブルが機械に発生しないことを確 認後, $\mathrm{BDF}$ 製造原料や電力量の寄与も実測し，すで 
に環境省 ${ }^{2)}$ 等から報告されている $\mathrm{CO}_{2}$ の発生係数を 利用して，化学的な知識があれば，容易にできる $\mathrm{CO}_{2}$ 削減量の簡易試算方法を提案するものである.

\section{2. 方 法}

伊賀 BDF 研究所ではワンダーランド200型の BDF 製造機を使用している。この手法による BDF の製造 工程を図 1 に示した。当所での合成法は典型的なアル カリ触媒・水洗法である。この工程は $\mathrm{CO}_{2}$ 削減シナリ オを考える上でも重要な部分でもあるので, 若干の説 明を加えておく，BDFの製造には，エステル化が必 要で, この反応にメタノール $(\mathrm{MeOH})$ と水酸化カリ ウム $(\mathrm{KOH})$ を利用し, 約 $60^{\circ} \mathrm{C}$ で加温し， 1 時間エ

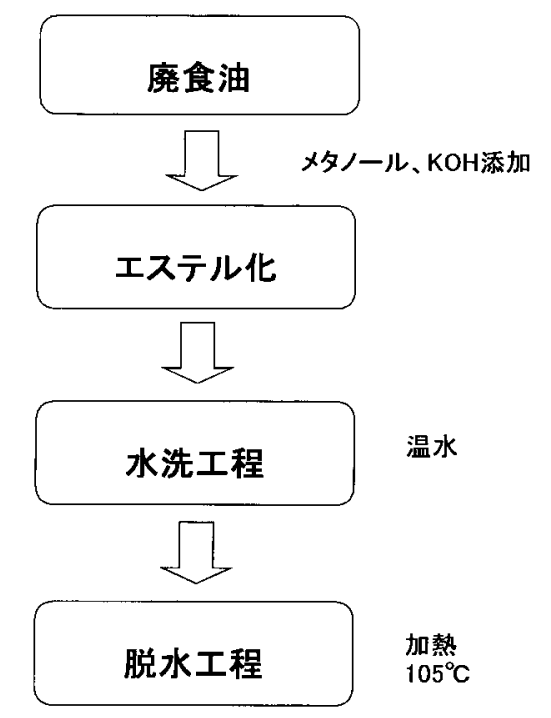

図 1 アルカリ触媒法による BDF 製造工程
ステル化をする．精製した BDFをグリセリンと分離 後, 夾雑物や副生物を除去する意味で水洗する。水洗 によって BDF 層には水分が蓄積され，エンジン稼動 に支障をきたすので，脱水工程でこれを除去し，孔径 $2 \mu \mathrm{m}$ のフィルターでろ過後, 燃料として利用する ものである.

廃油，メタノール，廃グリセリンおよび排水量等は 調整マスに刻印を行い，稼働前後の変化によって使用 体積を求めた．電力量の測定は本体のブレーカー（6 個）に計測器（自作）を接続し、1サイクルに必要量 を求めた。な扮， $\mathrm{KOH} の \mathrm{CO}_{2}$ 発生係数が見当たらな かったので，LCA 計算ソフトウェア（JEMAI-LCA Pro）を用いて計算した ${ }^{3)}$.

BDF の品質に関しては, 密度 (浮子式), 動粘度 (B 型回転式粘度計), 酸価と水分量（電量滴定方式）, 高 級脂肪酸エステル濃度 (FAME) (GC/FID) で求めた. 標準には混合標準を用いた。残存するトリグリセライ ドはHPLC/RIによって, トリオレンを標準として求 めた。また, BDF と廃グリセリンの発熱量はボンベ 熱量計（委託試験）で求めた。廃グリセリン中のメ夕 ノールは委託分析 (GC 法), $\mathrm{K}$ は $\mathrm{HNO}_{3}-\mathrm{HClO}_{4}$ 分解 後 ICP-AES で，グリセリンはHPLC/RI で，水分は 電量滴定法で実施した。表 1 には機器分析の条件をま とめた.

\section{3. 結果と考察}

\subsection{BDF の品質}

得られた結果を表 2 に示した。密度 $\left(15^{\circ} \mathrm{C}\right)$ の平均 值は $\rho=0.884 \mathrm{~g} / \mathrm{mL}$ であった。動粘度 $\left(40^{\circ} \mathrm{C}\right)$ も密度

表 1 機器分析の条件

\begin{tabular}{|c|c|c|c|}
\hline $\begin{array}{l}\text { HPLC } \\
\text { グリセリン }\end{array}$ & $\begin{array}{l}\text { カラム } \\
\text { 移動相 } \\
\text { 検出器 } \\
\text { 流速 }\end{array}$ & $\begin{array}{l}\text { Carbohydrate } \\
\text { アセトニトリル / 水 } \\
\text { 示差屈折率 } \\
0.8 \mathrm{~mL} / \mathrm{min}\end{array}$ & $\begin{array}{l}25 \mathrm{~cm} \times 4.6 \mathrm{~mm} \phi \\
=85 / 15(\mathrm{~V} / \mathrm{V} \%)\end{array}$ \\
\hline $\begin{array}{l}\text { HPLC } \\
\text { トリグリセライド }\end{array}$ & $\begin{array}{l}\text { カラム } \\
\text { 移動相 } \\
\text { 検出器 } \\
\text { 流速 }\end{array}$ & $\begin{array}{l}\text { Mightysil Si-60 BDF } \\
\text { n-へキサン/イソプロパノール } \\
\text { 示差屈折率 } \\
1.0 \mathrm{~mL} / \mathrm{min}\end{array}$ & $\begin{array}{l}25 \mathrm{~cm} \times 4.6 \mathrm{~mm} \phi \\
=99.6 / 0.4 \quad(\mathrm{~V} / \mathrm{V} \%)\end{array}$ \\
\hline $\begin{array}{l}\mathrm{GC} \\
\text { 脂肪酸エステル }\end{array}$ & $\begin{array}{l}\text { カラム } \\
\text { カラム温度 } \\
\text { 気化室温度 } \\
\text { キャリヤーガス } \\
\mathrm{H}_{2} \\
\text { Air } \\
\text { 検出器 } \\
\text { スプリット比 }\end{array}$ & $\begin{array}{l}\text { BD-WAX } \\
\mathrm{He} \\
\text { FID }\end{array}$ & $\begin{array}{l}30 \mathrm{~m} \times 0.5 \mu \mathrm{m} \text { (膜厚) } \\
220^{\circ} \mathrm{C}(20 \mathrm{~min}) \rightarrow 220 \sim 240^{\circ} \mathrm{C}\left(10^{\circ} \mathrm{C} / \mathrm{min}\right) \\
200^{\circ} \mathrm{C} \\
30 \mathrm{~mL} / \mathrm{min} \\
40 \mathrm{~mL} / \mathrm{min} \\
200 \mathrm{~mL} / \mathrm{min} \\
280^{\circ} \mathrm{C} \\
20\end{array}$ \\
\hline
\end{tabular}


表 2 製造した BDF の物性値

\begin{tabular}{cccccc}
\hline & 密度 $(\mathrm{g} / \mathrm{mL})$ & 動粘度 $\left(\mathrm{mm}^{2} / \mathrm{s}\right)$ & 酸価 $(\mathrm{mg}-\mathrm{KOH} / \mathrm{g})$ & 水分 $(\mathrm{mg} / \mathrm{L})$ & 純度 $(\%)$ \\
\hline 平成21年 7月31日 & 0.884 & 4.568 & 0.255 & - & 90.5 \\
8月 7日 & 0.885 & 4.568 & 0.200 & - & 90.2 \\
9月25日 & 0.884 & 4.595 & 0.327 & 680 & 92.1 \\
10月10日 & 0.885 & 4.594 & 0.224 & 495 & 91.1 \\
11月12日 & 0.885 & 4.589 & 0.243 & 680 & 93.6 \\
平成22年 1月22日 & 0.884 & 4.599 & 0.222 & 500 & 90.7 \\
3月16日 & 0.884 & 4.583 & 0.236 & 780 & 92.6 \\
5月21日 & 0.884 & 4.594 & 0.264 & 853 & 91.4 \\
6月 1日 & 0.884 & 4.599 & 0.200 & 870 & 89.7 \\
7月6日 & 0.884 & 4.599 & 0.318 & 882 & 91.3 \\
\hline
\end{tabular}

密度 $15^{\circ} \mathrm{C}$ 測定, 動粘度 $40^{\circ} \mathrm{C}$ 測定

表 3 製造した BDF の配送による $\mathrm{CO}_{2}$ 発生量試算

\begin{tabular}{|c|c|c|c|c|c|}
\hline 配布先 & 車 種 & 燃費 $(\mathrm{km} / \mathrm{L})$ & 距離 $(\mathrm{km})^{*}$ & 回 数 & 発生 $\mathrm{CO}_{2} \mathrm{~kg}$ \\
\hline 伊勢農場 & 三菱トラック & 15 & 26 & 8 & 36.6 \\
\hline 公 社 & スバルサンバー ${ }^{* *}$ & 15 & 17.2 & 15 & 39.9 \\
\hline \multirow[t]{2}{*}{ 長田友の会 } & ホンダ軽トラ ** & 10 & 13.2 & 18 & 55.1 \\
\hline & & & & 計 & 131.6 \\
\hline
\end{tabular}

*: 往復, **:2.32を係数として利用, 残りは2.64を利用

同様に B100のニート基準值（混合 FAME 品質規格，

JIS-K2390）内に収まっていた，酸価は大部分の試料 で $0.3 \mathrm{mgKOH} / \mathrm{g}$ 未満であり,ニート基準值内であった。 $\mathrm{BDF}$ を 1 か月放置してもこの值の著しい増加は認め られなかった：しかし，水分は500〜1000ppm とニー 卜基準より 2 倍ほど高かった。FAME 純度も $90 \%$ 程 度であり，1 段反応ではこれ以上純度を上げることは 困難のように思えた。なお，トリグリセライドの存在 量はニート基準未満であった。

施設に持ち込まれた他の BDF 製造所検体分につい ても同じ項目を分析した。密度，動粘度扮よび酸価は 大部分がニート基準值以内であった。しかし FAME についは，やや低い場合も認められた。なお，傾向と して家庭からの廃食用油を原料にする製造所の場合, 明瞭なトリグリセライドのピークが認められることが あった。また，大部分の試料では水分が1000ppmを 超過していた，水分については，容器中の残存水分量 が無視できず，大部分の試料はポリ容器に採取され， これから，分取されているので，採取法を考える必要 があるように思われた。

本施設で製造した BDFによる農機具の稼働および 車の走行上の問題点を聞き取りしたが大きなトラブル は見当たらなかった。したがって，この品質で十分と 判断し $\mathrm{CO}_{2}$ 削減試算に移った。

\subsection{CO2削減量の簡易試算法}

この計算の境界については以下のように決定した。 $\mathrm{BDF}$ 製造所で製造した $\mathrm{BDF}$ はその $10 \%$ が BDF 車に よる廃食用油の収集に利用されている（したがって， カーボンニュートラルから計算しない)， $82 \%$ は協力 団体で，農機具に燃料として使用されている（カーボ ンニュートラルから計算しない)，しかし，製造した BDF の現地輸送には化石燃料を利用するトラックを 利用している。そこで， $\mathrm{CO}_{2}$ 発生の寄与を推定するた め往復距離，燃費等から発生する $\mathrm{CO}_{2}$ を試算した。 そ の結果を表 3 に示した。表了からわかるように，往復 距離が小さいことから，この寄与は年間で $131 \mathrm{~kg}-\mathrm{CO}_{2}$ と比較的小さなものであった，また，伊賀ではメ夕ノー ルと水酸化カリウムは BDF 装置納入者が BDF 車で 運送するのでカウントしていない，

図 2 には 1 年間の BDF 製造量変化を示した. BDF 製造にやや増減が認められる。当初は週 1 回の稼働で あったが，11月以降は原則として週 2 回の稼働を実施 している。廃食油100L を利用する 1 回の操作から96L の $\mathrm{BDF}$ が製造される。この期間中 86 回の製造を行っ たので，年間 BDF 製造量は

$$
96 \mathrm{~L} \times 86 \text { 回 }=8256(\mathrm{~L} / \text { 年 })
$$

である. $\mathrm{CO}_{2}$ の発生量削減試算のためには以下に述べ 


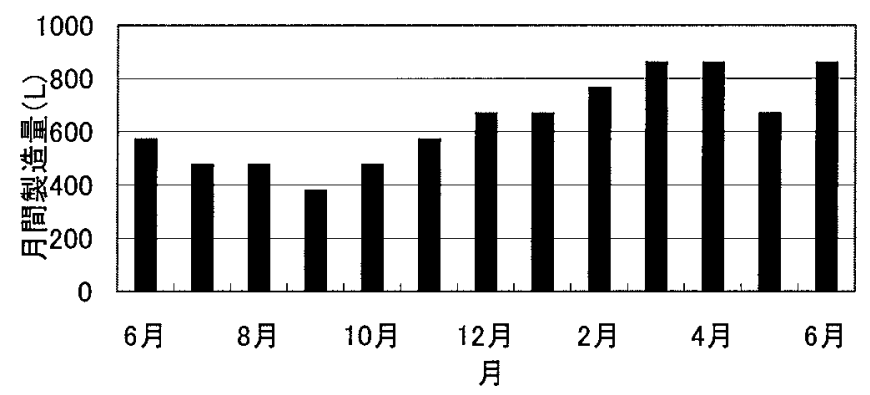

図 2 平成21年 6 月から平成222年 6 月までの月間 BDF 製造量变化

る5つの場合を考慮することにした。すなわち，

(1)シナリオ (I) 単純計算：平成21年 6 月から 22 年 6 月までの BDF 製造量は8256Lである。したがって これが軽油と同レベルの燃料価值があるから, 発生 係数 $2.64 \mathrm{~kg}-\mathrm{CO}_{2} / \mathrm{L}$ を利用すると，

$$
8256 \mathrm{~L} \times 2.64=21796 \mathrm{~kg}-\mathrm{CO}_{2}
$$

の $\mathrm{CO}_{2}$ を削減したことになる。この近似法は, $\mathrm{NPO}$ や自治体で簡便であることからょく採用され ている。しかし，BDF と軽油では発熱量が異なる ので, これを加味しなくてはならない.

(2)シナリオ (II) 発熱量換算をした場合：発熱量 (BDF : $39.7 \mathrm{MJ} / \mathrm{kg}$ (実測值) と軽油 : $45 \mathrm{MJ} / \mathrm{kg}$ ) と密 度 $\left(15^{\circ} \mathrm{C}, \mathrm{BDF}=884 \mathrm{~kg} / \mathrm{m}^{3}\right.$, 軽油注 $\left.)=834 \mathrm{~kg} / \mathrm{m}^{3}\right)$ を 考慮すると, この值は軽油 $=7720 \mathrm{~L}$ に相当するので,

$$
7720 \mathrm{~L} \times 2.64=20381 \mathrm{~kg}-\mathrm{CO}_{2}
$$

の削減になる。さらに, $\mathrm{BDF} の$ 製造には, $\mathrm{KOH}$ と $\mathrm{MeOH}$ が原料として不可欠である。

(3)シナリオ（III）副原料を考慮した場合： $\mathrm{MeOH} の$ $\mathrm{CO}_{2}$ 発生係数 $=1.5 \mathrm{~kg}-\mathrm{CO}_{2} / \mathrm{kg}-\mathrm{MeOH}$ と密度 $(=785$ $\left.\mathrm{kg} / \mathrm{m}^{3}\right)$ ，また， $\mathrm{KOH}$ の使用も不可欠であることか ら $\mathrm{KOH}$ の $\mathrm{CO}_{2}$ 発生係数 $=4.12 \mathrm{~kg}-\mathrm{CO}_{2} / \mathrm{kg}-\mathrm{KOH}$, $\mathrm{MeOH}$ は22L/回, $\mathrm{KOH}$ は880g/22LMeOH の使用 量を考慮すれば,

$$
\begin{aligned}
& 20381-2219(\mathrm{MeOH})-312(\mathrm{KOH}) \\
& \quad=17850 \mathrm{~kg}-\mathrm{CO}_{2}
\end{aligned}
$$

の削減になる. BDFの製造には電気も不可欠である.

$$
\text { 注 }
$$

·社石油学会 ; 軽油標準物質
(4)シナリオ（IV）電力量を考慮した場合：図 3 には, 各工程の使用電力量の実測值を示した。電力量を測 定した結果, 大きな電力が反応炉の加熱 (エステル 化 : $\left.60^{\circ} \mathrm{C}\right)$ と脱水 $\left(105^{\circ} \mathrm{C}\right)$ に使用されていることがわ かった.さらに, 送液用のポンプ, 攪拌用のモーター 等も電力量を実測したがこれらに比べると微々たる ものであった. 電力量として平均 $10 \mathrm{kwh} /$ 回の結果を 得た. 中部電力 ${ }^{4)} の \mathrm{CO}_{2}$ 発生係数 $=0.481 \mathrm{~kg}-\mathrm{CO}_{2} / \mathrm{kwh}$ から,

$10 \mathrm{kwh} /$ 回 $\times 86$ 回 $\times 0.481=414 \mathrm{~kg}-\mathrm{CO}_{2}$ よって,

$$
17850-414=17436 \mathrm{~kg}-\mathrm{CO}_{2}
$$

の削減量になる。なお，使用する水については $\mathrm{CO}_{2}$ 発生係数 $=0.58 \mathrm{~kg}-\mathrm{CO}_{2} / \mathrm{m}^{3}(\text { 環境省 })^{2)}$ を用いても 極めて少ないので無視した。

(5)シナリオ $(\mathrm{V})$ ：境界システムを考慮した場合：初 めにも述べたように製造した BDF の運搬には燃料 に化石燃料を利用しているので，この寄与分 $131 \mathrm{~kg}$ を差し引くと

$$
17436-131=17305 \mathrm{~kg}-\mathrm{CO}_{2}
$$

である。全体の結果を図 4 に示した.

したがって, BDFの製造量から単純に推定した削 減量 $=21796 \mathrm{~kg}-\mathrm{CO}_{2}$ に比へてて, 発熱量, 原料, 電力 量抄よび境界システムを考慮するとその削減量= $17305 \mathrm{~kg}-\mathrm{CO}_{2}$ になることがわかった。

以上の考察では副生するグリセリン（以下廃グリセ リン）の寄与は無視されている。現実には，廃グリセ リンが存在するので, この寄与を推算した。1 回の $\mathrm{BDF}$ 製造で20L の廃グリセリンが副生する。したがっ て，年間では 


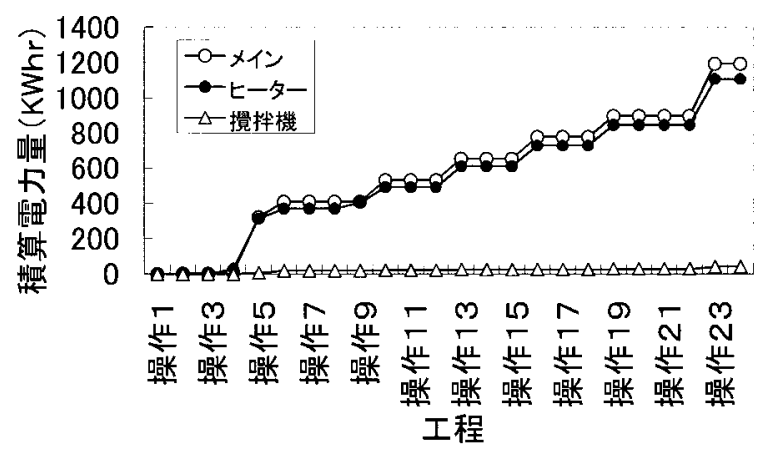

図 3 工程毎の使用電気量

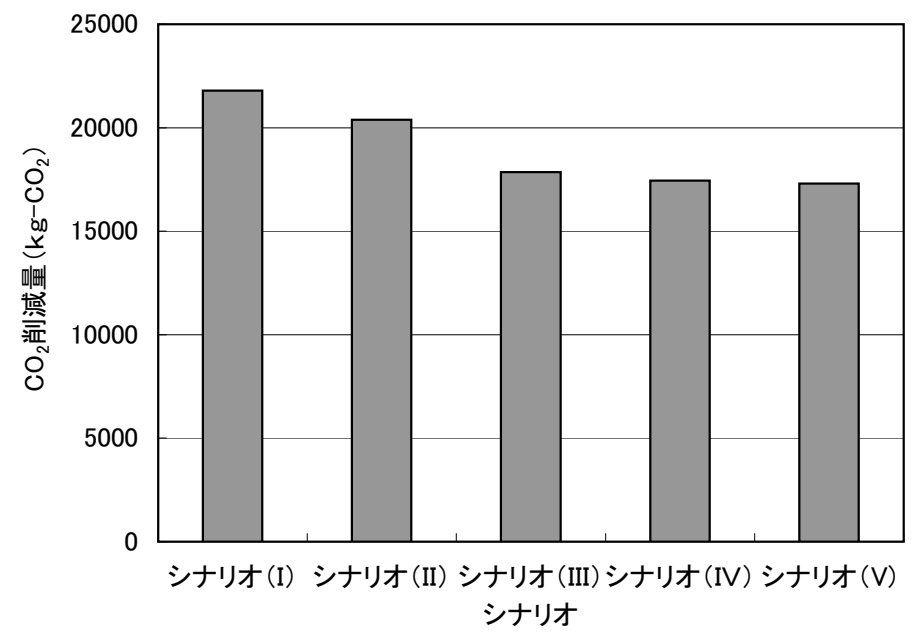

図 4 シナリオに見た $\mathrm{CO}_{2}$ 削減量変化

$20 \mathrm{~L} \times 86$ 回 $=1720 \mathrm{~L}$

となる。この廃グリセリンの組成分析は困難で, 分析 した範囲では, グリセリン 30 40\%, 水分 $1 〜 2 \%$, メタノール10１3\%，カリウム $3 \sim 5 \%$ であった．残 りの $50 \%$ 程度の成分は不明である。実測によれば，廃 グリセリンの発熱量は $25.5 \mathrm{MJ} / \mathrm{kg}$ であった。したがっ て, 廃グリセリンの密度 $\left(15^{\circ} \mathrm{C}\right)=1040 \mathrm{~kg} / \mathrm{m}^{3}$ を考慮し， 軽油との発熱量換算を実施すると,この体積は,

$$
\begin{aligned}
& 1720 \times(1040 \times 25.5 \times 0.001) /(834 \times 45 \times 0.001) \\
& \quad=1215(\mathrm{~L}-\text { 軽油 })
\end{aligned}
$$

となる.

ところで，筆者らが BDF の研究を始めた平成13年 頃は, この廃グリセリンは厄介物で, 製造者が有償で 処理を業者に委託していた。しかし，数年前における
燃料の高騰化がこの状態を変えた。すなわち, 聞き取 り調査によれば，現在三重県では廃グリセリンは 0 〜 10円/L程度で, 処理業者が引き取っている。 そして, 軽油等と混ぜて, ボイラーの補助熱源として利用され ているとのことである。したがって，このことを考慮 すると, 前述の軽油対応量に $\mathrm{CO}_{2}$ の発生係数を乗じた $\mathrm{CO}_{2}$ 量は，通常の化石燃料よりも $\mathrm{CO}_{2}$ 発生の低減に寄 与すると考えられるので，シナリオ（V) に加える必 要がある．この值 $(1215 \times 2.64=3207)$ を加味すると， $\mathrm{CO}_{2}$ の削減試算は年間で $20512 \mathrm{~kg}-\mathrm{CO}_{2}$ となる。 ただし, これはあくまでも計算上で，廃グリセリンの運搬等で 化石燃料を使えば，また別の計算になることは言うま でもない.

\section{4. まとめ}

伊賀 BDF 研究所で製造したBDFの品質および 
$\mathrm{BDF}$ 製造に伴う $\mathrm{CO}_{2}$ 削減量の簡易試算を既存の発生 倸数から推定した。 その結果,

1） 1 年間にわたり試験運用したが，重大なエンジン トラブルはなかった。

2 ）密度，動粘度，酸価は全てニート基準を満足して いた。 しかし，水分は400 800ppm でニート基準の 約 2 倍高かった. FAME 純度は $90 \%$ 前後であったが, トリグリセライドは基準以下であった。

3 ）年間 BDF の製造量は8256Lで，これを基礎に削 減 $\mathrm{CO}_{2}$ 量を試算したところ, 単純計算では $21796 \mathrm{~kg} の$ $\mathrm{CO}_{2}$ 量が削減された。ささらに, 軽油との発熱量換算を 実施すると，この值は20381 kg-CO2 となった，BDF の製造試薬（KOH とメタノール）を加味すると，こ の值は $17850 \mathrm{~kg}-\mathrm{CO}_{2}$ となった，さらに，電気量を考慮 すると $17436 \mathrm{~kg}-\mathrm{CO}_{2}$ まで減少した。 なお，電力量の中 で寄与率が大きいのは, 反応工程 $\left(60^{\circ} \mathrm{C} ， 1\right.$ 時間）と 脱水工程 $\left(105^{\circ} \mathrm{C} ， 1\right.$ 時間）であった.

4 ）モデルの境界に位置する廃食用油と BDF の運搬 過程で発生する $\mathrm{CO}_{2}$ 量は, $131 \mathrm{~kg}-\mathrm{CO}_{2} て ゙$, 電力量の寄
与からさらに差し引くと， $17305 \mathrm{~kg}-\mathrm{CO}_{2}$ となった

5 ）副生するグリセリンが補助燃料として利用されて いることを考慮すると，この值は増加し， $20512 \mathrm{~kg}-$ $\mathrm{CO}_{2}$ となった。

発生係数を利用すると,このようにより現実に近い 条件で, 複雑な LCA ソフトを利用しなくても $\mathrm{CO}_{2}$ 削 減量が試算できるのではないかと思われる。(なお, 本研究は, 農水省: 高度バイオマスタウン構想推進の 補助金によって実施した)。

\section{参考文献}

1 ）竹内淨, 盛田宗利, 鈴木利康, 石田哲夫, 小倉隆, 井上 雄一, 伊中悦子, 飯嶋渡; 廃喰油燃料化事業に打ける二 酸化炭素削減効果の LCA 的評価，第32回環境・公害研 究合同発表会予講演集 (神奈川県), 9-12,2008.

2 ) 環境省; 環境家計簿（2008年版）および三重県：環境連 携三重の環事業, 28-32,2005.

3 ) (社) 産業環境管理協会：JEMAI-LCA Pro, (オンライン) $\langle\mathrm{http} / / / \mathrm{www}$.jemai.or.jp/CACHE/lca_details_lcaobj6. cfm〉, (参照2010.11.01).

4 ) 中部電力; 中部電力二酸化炭素 $(\mathrm{CO} 2)$ 排出量の推移, (才 ンライン ), 〈http://www.jt-sys.co.jp/business/keisuu. $h t m l\rangle, \quad($ 参照2010.11.01).

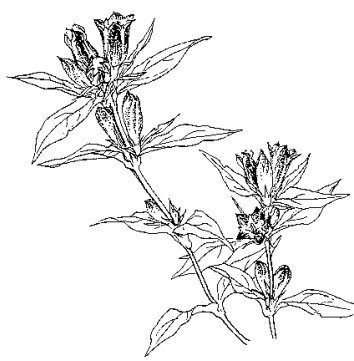

